\title{
Socio-economic Impact of Traditional Technology of Charcoal Production in Kpaai District-Bong County Liberia
}

\author{
Sunday Oladipo Oladeji (Corresponding author) \\ Department of Ecotourism and Wildlife Management, Federal University of Technology \\ Akure, P. M.B. 704, Akure, Ondo-State, Nigeria
}

Tel: 234-803-069-8896_E-mail: sooladeji@futa.edu.ng, oladejisunny@yahoo.com

\author{
Oluyemi Phillips Ologunwa \\ Department of Economics, School of Management Technology \\ Federal University of Technology, P. M.B. 704, Akure, Ondo-State, Nigeria
}

Tel: 234-803-409-8155Ｅ-mail:ddesykay@yahoo.com

\section{Bendu Too Tonkollie}

Central Agricultural Research Institute (CARI), Suakoko, Bong County, Liberia

Tel: 231-770-278-685Ｅ-mail: bendutoo195@gmail.com, bendutoo@gmail.com

Received: August 30, 2017 Accepted: September 15, 2017 Published: March 16, 2018

doi:10.5296/emsd.v7i2.11770 URL: https://doi.org/10.5296/emsd.v7i2.11770

\begin{abstract}
Abstarct
Locally produced charcoal through traditional technology is a source of income to the inhabitants of Kpaai district, Bong-County, Liberia and this has invariably contributed significantly to the country Gross Domestic Product. Two sets of questionnaires were designed and administered randomly to eighty seven consumers and fifty five producers representing sample intensity of between $54-68 \%$ and $10-10.3 \%$ respectively in five communities among the clans of Waytuah and Wotola. Field observation and Interview data collected were descriptively analysed using SPSS 20. Three traditional earth kiln methods of charcoal production were identified among the producers that are mostly male
\end{abstract}


(69.20-85.10\%). Women representing $61.20-82.70 \%$ of the consumer in the age range of 21-30 years (36.4-71.40\%) were spending between 13-25\% of their income on charcoal. Producers have recorded various achievement from the income range of between LD5, 000-20,000 realized monthly. Dirty of their bodies and houses, sicknesses, generating smoke and ash dust were the forms of social economic impact being encountered. Research findings will assist Liberia Government in developing appropriate modern technology for efficient charcoal production and sustainable energy generation as part of REDD + implementation process.

Keywords: Charcoal production, Economic impact, Source of income, Sustainable energy, Traditional Technology, Producers, Social, Earth klin

\section{Introduction}

The dark grey residue consisting of carbon and any remaining ash, produced the slow Pyrolysis process of heating wood and other substances in the absence of oxygen is considered as charcoal (Ogara, 2011). This task can be achieved by burning wood under high temperature in the absence of air or oxygen (ARBT, 2006, Cunhan, 2012). Charcoal can be produced at different levels depending on the available materials, technological know-how and available manpower. There are different methods of producing charcoal either in commercial quantity or in subsistent based on the types of kilns used. The identified different types of Kiln according to literatures include earth kilns, brick and metal kilns (FAO, 1987, Ukraine Biofuel Suppliers, 2016). It equally revealed that today the most popular methods for commercial production of charcoal include steel and brick kilns as they are easy to use, could carbonize even poor quality wood thereby produces high quality charcoal (Ukaine Biofuel Suppliers, 2016). The carbonization cycle of steel kilns is much quicker than others and lasts 16-24 hours, wherein it is highly automated (The Schumacher Centre for Technology and Development Bourton-on-Dunsmore, 2005).

Whereas, in the simplest traditional method, the process could takes more than a day or two as a result of unpredictable environmental factors like rainfall or perlo filtration of air during production. For instance, the advent of rainfall in the course of production, might make the process inadvertently ineffective leading to charred or dark grey residues unrecovered since the wood is burned in an open space. A more controlled process is by restricting the supply of air during carbonization. The most common earth kilns for small scale production and subsistence as practised in many developing countries are the traditional and improved earth kilns. Mungo and Ong, 2006, gave a clear distinction between traditional and improved earth kiln. The authors illustrated the traditional earth kiln as stacking the wood on the ground and covered it with soil, forming what is often referred to as an earth mound kiln. However, the other improved earth Klin method involves digging a hole in the ground into which the wood is placed and then covered with soil, this one is commonly referred to as a pit-kiln method. The traditional method is the earliest method of charcoal production based on using earth pit kilns. Although, it is still a very popular technology, but it entails considerable knowledge and experience, as well it must be completely rebuilt after each cycle.

The modern method of charcoal production are differentiated based on the techniques involve 
including metal jumbo kiln, Beehive kiln (Brazilian type), Conical earth mound kiln, earth mound kiln, Masonry kilos (Half orange Argentinean and Brazilian design) and Paralytic drum technique (Netherlands Programme Sustainable Biomass, 2013). The brick kilns are represented by the Argentine half orange Kiln and the Brazilian beehive kiln and the metal kilns by the drum kiln (Ukranian Biofuel Suppliers, 2016).

Whatsoever the process and techniques that were undertaken during production, the ultimate aim is to accomplish the recovery of charcoal either in commercial or subsistence quantity. Charcoal is a modern source of energy for cooking in both rural and urban areas with large number of rural dwellers usually involved in its production (Obayelu et al., 2017). Ministry of Land, Mines and Energy Ministry of Land, Mines and Energy (MLME) (2009), opined that almost all charcoal is produced in the rural areas, with large proportions of raw materials extracted from woodlands. This is also in tandem with Jamala et al., (2013), that half of the world's population use biomass fuels for cooking and that in 1992, 24 million tons of charcoal were consumed worldwide, with developing countries accounting for nearly all consumption while Africa alone accounted for 50\%. Postulate to findings of Ogara, (2011) that most people $(68.34 \%)$ in Nassarawa State, in Nigeria are involved in Charcoal making and $57-100 \%$ of the people are involved in charcoal production as a means of generating income.

The impact of charcoal production on human health and the environment have been reported in literatures (Oguntade et al., 2008; Nwofe, 2013, Wahabu et al., 2015). The authors emphasized the impact of charcoal production to include impact on soil minerals, disorder and depletion of the ozone layer. There are indications that the depletion of ozone layer is now a global phenomenon which many scientists have attributed to the unpredictable climate change with cumulative effect on food production and the global increase in diseases. Ogara, 2011, opined that though charcoal gives advantage of heating efficiency, the environmental problems of deforestation resulting from the use of a large number of trees and pollution from smoke and its constituents in the production process are requiring immediate attention across various academic disciplines like ecology, social and earth sciences. Henceforward, the aftermath effects of these impact cannot be ignored, thus proactive actions needed to be taken.

As demand for charcoal increases with rapid urbanization, so does pressure on rain forests, mangroves and woodlands, most of which are poorly managed and prone to degradation. Stefan, (2009), observed that depletion of forest resources and pollution of air form part of environmental impacts of charcoal production in Ethiopia. Msuya, et al., (2011) estimated the combined effects of charcoal production and use at about 49700 000, 9830 000, 1109000 and 12478000 tons of carbon dioxide, Nitrogen oxide, Sulphur dioxide and Methane respectively in Tanzania. The effects of releasing these gaseous substances into the atmosphere during charcoal production is considered to be unfriendly to the environment as it creases greenhouse gases thereby necessities conservation and planting of trees to combat these menace .

Despite these aforementioned health, ecological and social negative impacts of charcoal 
production, the economic impact of charcoal production and consumption in many rural areas in developing countries still on increase. This increase is posed to continue due to many reasons as cited in literatures. For instance, findings from literatures revealed that demand for this energy source in Sub-Sahara Africa will not remain stagnant but will increase dramatically through the year 2030 (Energy Information Administration, 2001). Despite increasing per capita income, higher electrification rates, and significant renewable energy potential, charcoal still remains the dominant source of cooking and heating energy for eighty percent of households in Sub Saharan Africa (SSA) (Arnold et al., 2006; Zulu and Richardson, 2013). Barely two decades ago, persistent hike in the price of kerosene, Premium Motor Spirit (PMS), and cooking gas in Nigeria was adjudged for increasing demand for firewood being collected from sawmills and nearby bushes (Oladeji, 1998). This situation has not improved as marked by attendance long queues in filling stations and Nigerians are still battling with social and economic hardship as a result of insufficient supply of Kerosine and other petroleum products. High rate of urbanization with incessant drop in the electricity supply, hike in electricity tariff and lack of alternative energy source except fuel collected from nearby sawmills and bushes were equally recounted. Karekezi, (2002) observed that between 1970 and 1990, the number of urban inhabitants without electricity in Africa increased from less than 40 million to 100 million. According to UNDP (2004), an estimate of 2.5 billion people lack access to modern energy services. It was reported that this has constrained their opportunities for economic development and improved living standards. Congruence to the findings of WHO , (2006) that some rural households in Africa rely on traditional biomass sources such as wood fuel, agricultural residues, and animal dung to meet their basic energy needs. WHO, (2006) further stated that fuel wood is predominantly used in the rural areas where the people have access to firewood while the urban areas mostly use kerosene stove, local gas cooker, local electric cooker, sawdust stove, charcoal stove and firewood as cooking fuels.

World Bank, 2014 provided in sight for the increasing demand for charcoal and fuelwood in some Africa countries to include increasing electrification rates. For instance, this apex financial institutions reported that countries like Nigeria or Ghana is making 60-70\% of the population to rely on the use of charcoal for cooking and heating due to hike in electrification rate. This support the claim of Audu, (2013), on the increasing tariff on electricity in Nigeria from $2.30 / \mathrm{KWH}$ to $11.75 / \mathrm{KWH}$ between 2000 and 2012 without proportional supply since relatively small percentage is connected to the National grid. The same thing was observed in Liberia where less than one percent of the population is connected to electricity grid thereby making $95 \%$ of the population to rely on traditional biomass fuels in the form of wood and charcoal (Goanue, 2009). African Development Bank Group Gender and Energy Desk Review, 2016 opined that although African continent boasts abundant energy resources (including fossil fuels and renewables), enough to meet its energy needs, but it is lacking on the supply side since more than two-thirds of the population lacks access to modern energy. According to the International Energy Agency (2014), 'in sub-Saharan Africa as a whole, only 290 million out of 915 million people have access to electricity.' This may not be enough reason for increasing demand for charcoal and other form of fuelwood in some Africa countries like South Africa. It was revealed that despite South Africa stands as the greatest 
electrified country on the continent, $90 \%$ of households in one study continued to utilize wood fuels (i.e. charcoal) even after ten years since gaining access to electricity (Madubansi and Shackleton, 2007). Similar results were found in Tanzania, Zimbabwe, Botswana and many others across the continent (Prasad, 2008 and Okello et al., 2013).

Availability of large expanse of forest area and aftermath effects of war have been identified as basis for increasing demand for fuel wood in Liberia. Liberia has a forest cover of more than $80 \%$ of its landscape and in gross terms, the annual production of fuel quality bio-mass substantially exceeds demand (Liberian Forestry Development Authority (LFDA), 2006). Given the abundance of Liberia's forests, fuel wood and charcoal have become the principal energy sources and consumption sky rocketed both during and after the war. LFDA noted that the demand for charcoal in what could be termed as urban consumption across the country continues to worsen the already uncontrollable harvesting of forest products. Monrovia is gradually growing at the rate of 4 - 5 percent per year after the civil war, upsetting the previous growth rate of 5 - 6 percent per year between 1983 - 1993 as reported by Energy Commission (FAO, 1998). FAO, 1998 concluded that urbanization and population increase form the basis for increasing charcoal and fuelwood demand in. Various estimates indicate that the entire population of Liberia country (up to 99 percent) is now dependent on charcoal and fuel wood to satisfy their basic need for cooking and heating (UNDP, 2004). UNDP, 2004, observed that in Liberia, charcoal production only contributed two percent of the Gross Domestic Product (GDP) in pre-war times, however in 1999 it accounted for nine percent. Reportedly, the export of charcoal to neighbouring countries suffering from lack of fuel wood due to deforestation poses a serious threat to Liberia's forests as trees are cut to meet the increasing regional demand (UNDP, 2004). In view of all these findings, observations and judgments, there is serious consideration to undertake a study targeted at assessing the socio-economic impact of charcoal production through traditional earth kiln methods on the livelihood of inhabitants of Kpaai District, Liberia.

Prior to the commencement of this research, result of the reconnaissance survey conducted revealed that charcoal consumption and trading is a common business among the inhabitants of Palala Town, Gbarnjata Town, Lorta, Lamco Camp (Green Hill Curry), and Zowienta Town representing Waytuah and Wolota Clans in Kpaai District, Bong. It was aslo observed that traditional earth kiln methods are predominatly used across these areas. Output from this research will serve as blueprint for developmental roadmap on sustainable energy consumption policy in Liberia.

\section{Methodology}

Stratified sampling technique was used in selecting the five communities representing Waytuah and Wolota clans in Kpaai District, Bong County, Liberia (Figure 1). Three towns were stratified in Waytuah Clan and two towns in Wolota Clan. This is because inhabitants from Waytuah Clan occupied larger communities than that of Wolota Clan. The name of the selected towns are Gbanja's Town, Palala Town, Green hill quarry town from Waytuah Clan; and Zowienta town and Loita town from Wolota Clan. Two sets of questionnaires were designed for the inhabitants in these communities. 


\section{Macrothink

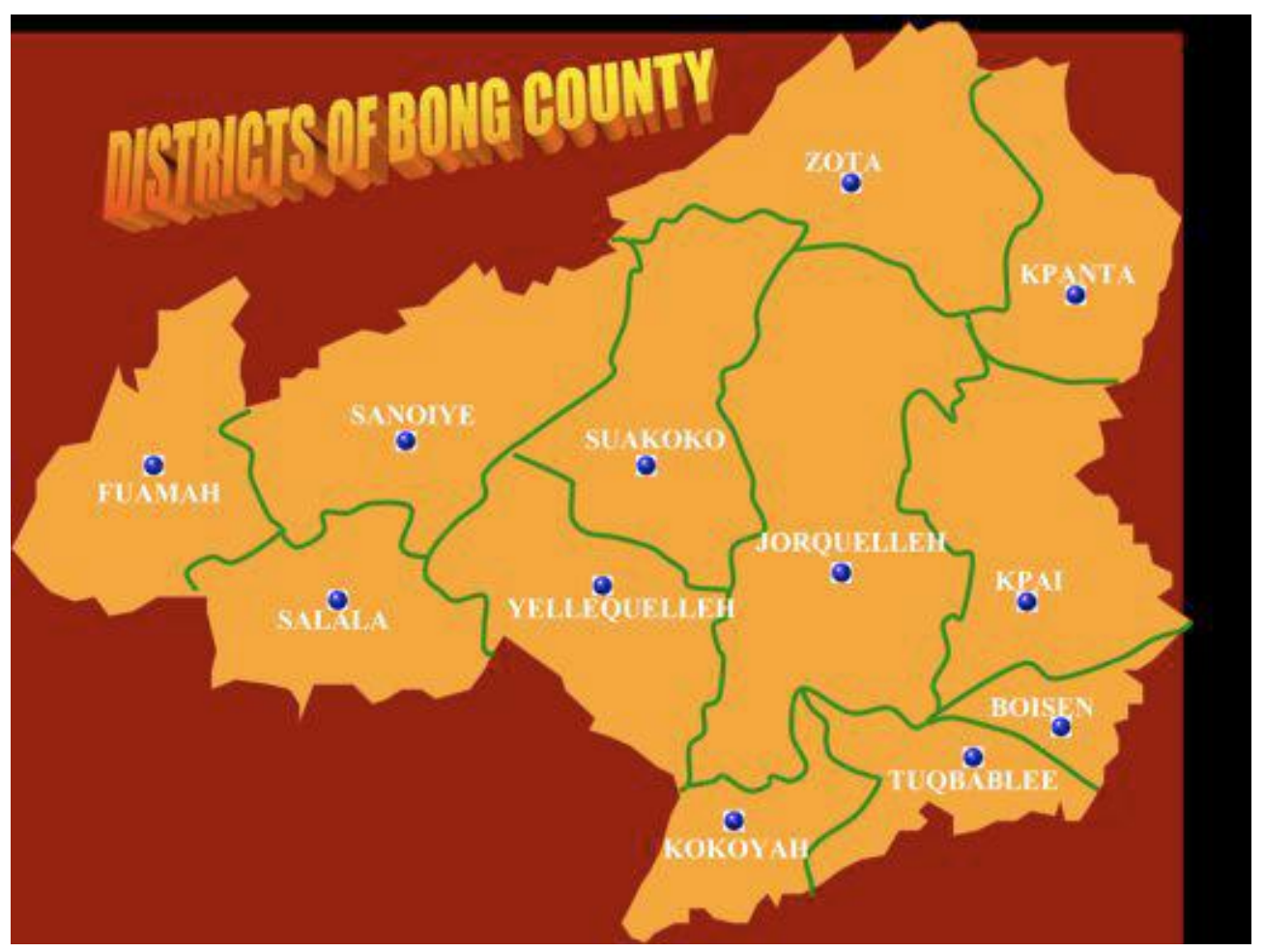

Figure 1. District of Bong County

A set of questionnaire was prepared and administered to the inhabitants that are charcoal producers while the second set of questionnaire was prepared and administered to the inhabitants that are consumers that are non-producers. This exercise involved both men and women of diverse age range. Eighty seven respondents were administered out of the population of eight hundred and fifty six inhabitants in the five selected communities while fifty five numbers of the ninety two producers were randomly selected. A total of one hundred and forty two questionnaires were administered in all. Sample size therefore varies between $10-10.3 \%$ for the consumers and $54-68 \%$ for the producers (table 1 and 2).

Other methods employed for the study include field observation and Key Informant Interview. Two key informants were selected in each community making a total of ten Key Informants in all. The informants include respondents that were not encountered during questionnaire administration and they must have spent minimum of fifteen years in these communities. Field observation was conducted through repeated visits to the neighboring markets in these communities where charcoal is being displayed for sales. Production sites and houses of the inhabitants were visited to ascertain the level of negative impacts on the respondents. The following are the sampling techniques involved both consumers and producers of charcoal 
Table 1. Sampling Technique for the consumers

\begin{tabular}{|l|l|l|l|}
\hline Town & Population $(\mathrm{n})$ & Sample size & Questionnaire administered \\
\hline Gbanja & 68 & $10.3 \%$ of 68 & 7 \\
\hline Palala & 306 & $10.1 \%$ of 306 & 31 \\
\hline GreenHill quarry & 136 & $10.2 \%$ of 136 & 14 \\
\hline Zoweita & 237 & $10.1 \%$ of 237 & 24 \\
\hline Loita & 109 & $10.1 \%$ of 109 & 11 \\
\hline Total & 856 & $10.2 \%$ of 856 & 87 \\
\hline
\end{tabular}

Source: Field Survey 2017

Table 2. Sampling Technique for the producers.

\begin{tabular}{|l|l|l|l|}
\hline Town & Population (n) & Sample size & Questionnaire Administered \\
\hline Gbanja & 12 & $58 \%$ of 12 & 7 \\
\hline Palala & 31 & $68 \%$ of 31 & 21 \\
\hline Green Hill quarry & 14 & $57 \%$ of 14 & 8 \\
\hline Zoweita & 24 & $54 \%$ of 24 & 13 \\
\hline Loita & 6 & $55 \%$ of 11 & 6 \\
\hline Total & 55 & $60 \%$ of 92 & 55 \\
\hline
\end{tabular}

Source: Field Survey 2017

\section{Results}

The descriptive statistical method was used to present and evaluate research data using tables and simple percentages.

\subsection{Demographic Characteristics of Respondents}

\subsubsection{Demographic Characteristic of the Respondents that are Consumers / Non-Producers}

The result of the descriptive analysis of administered questionnaire to the consumers or non-producers at the five selected towns in Kpaai districts revealed that greater percentage of the respondents are in the age group of 20-30years $(71.40 \%, 54.2 \%, 51.60 \%, 42.9 \%$ and $36.40 \%)$, female represented the highest percentage $(71.40 \%, 61.2 \%, 85.70 \%, 58.30 \%$ and $63.60 \%)$, majority of the respondents are unmarried or single $(85.70 \%, 61.30 \%, 71.40 \%, 70.80 \%$ and $54.50 \%$ ), the inhabitants are Liberians except in Gbanja where $85.70 \%$ of the respondents are non-Liberians, greater percentage of the respondents are private workers this include traders, artisans, business women and men ( 64.50\%,42.90\%,50.00\%, 54.60\%), however students constituted $85.70 \%$ of the respondents in Gbanja (Table 3a). 
Table 3a. Demographic characteristic of the respondents that are consumers / non-producers

\begin{tabular}{|c|c|c|c|c|c|c|c|c|c|c|}
\hline \multirow{2}{*}{$\begin{array}{l}\text { Variable } \\
\text { Age }\end{array}$} & \multicolumn{2}{|c|}{ Towns Gbarnja } & \multicolumn{2}{|c|}{ Palala } & \multicolumn{2}{|c|}{ Green hill quarry } & \multicolumn{2}{|c|}{ Zoweita } & \multicolumn{2}{|c|}{ Loita } \\
\hline & No & $\%$ & No & $\%$ & No & $\%$ & No & $\%$ & No & $\%$ \\
\hline $10-20$ & 0 & 0.00 & 0 & 0.00 & 2 & 14.30 & 4 & 16.70 & 1 & 9.10 \\
\hline $20-30$ & 5 & 71.40 & 16 & 51.60 & 6 & 42.90 & 13 & 54.20 & 4 & 36.40 \\
\hline $30-40$ & 1 & 14.30 & 2 & 6.50 & 3 & 21.40 & 3 & 12.50 & 4 & 36.40 \\
\hline 40 above & 1 & 14.30 & 13 & 42.00 & 3 & 21.40 & 4 & 16.70 & 2 & 18.20 \\
\hline \multicolumn{11}{|l|}{ Gender } \\
\hline Male & 2 & 28.60 & 12 & 38.70 & 2 & 14.30 & 10 & 41.70 & 4 & 36.40 \\
\hline Female & 5 & 71.40 & 19 & 61.20 & 12 & 85.70 & 14 & 58.30 & 7 & 63.60 \\
\hline \multicolumn{11}{|l|}{ Marital status } \\
\hline Married & 1 & 14.30 & 12 & 38.70 & 3 & 21.40 & 7 & 29.20 & 5 & 45.50 \\
\hline Single & 6 & 85.70 & 19 & 61.30 & 10 & 71.40 & 17 & 70.80 & 6 & 54.50 \\
\hline Widow/widower & 0 & 0.00 & 0 & 0.00 & 1 & 7.10 & 0 & 0.00 & 0 & 0.00 \\
\hline \multicolumn{11}{|l|}{ Religion } \\
\hline Islam & 1 & 14.30 & 2 & 6.50 & 0 & 0.00 & 2 & 8.30 & 0 & 0.00 \\
\hline Christianity & 6 & 85.70 & 28 & 90.30 & 14 & 100.00 & 20 & 83.30 & 9 & 81.80 \\
\hline Others & - & 0.00 & 1 & 3.20 & 0 & 0.0 & 2 & 8.30 & 2 & 18.20 \\
\hline \multicolumn{11}{|l|}{ Occupation } \\
\hline Student & 6 & 85.70 & 10 & 32.30 & 6 & 42.90 & 10 & 41.70 & 5 & 45.50 \\
\hline Civil servant & 0 & 0.00 & 1 & 3.20 & 2 & 14.30 & 2 & 8.30 & 0 & 0.00 \\
\hline Privatework e.g Traders & 1 & 14.30 & 20 & 64.50 & 6 & 42.90 & 12 & 50.00 & 6 & 54.60 \\
\hline \multicolumn{11}{|l|}{ Nationality } \\
\hline Liberian & 2 & 28.60 & 19 & 61.30 & 11 & 78.50 & 17 & 70.80 & 7 & 63.60 \\
\hline Non-Liberian & 5 & 71.40 & 12 & 38.70 & 3 & 21.40 & 7 & 29.20 & 4 & 36.40 \\
\hline \multicolumn{11}{|l|}{ Level of Education } \\
\hline Primary & - & 0.00 & 1 & 3.20 & 7 & 50.00 & 7 & 29.20 & 2 & 18.20 \\
\hline Secondary & 6 & 85.70 & 15 & 48.40 & 5 & 35.70 & 13 & 54.20 & 7 & 63.60 \\
\hline Tertiary & 1 & 14.30 & 14 & 45.20 & 0 & 0.00 & 4 & 16.70 & 2 & 18.20 \\
\hline Illiterate & 0 & 0.00 & 1 & 3.20 & 2 & & 0 & 0.00 & 0 & 0.00 \\
\hline \multicolumn{11}{|l|}{ Monthly Income } \\
\hline$<5,000$ & 3 & 42.9 & 17 & 54.8 & 6 & 42.90 & 12 & 50.00 & 6 & 54.60 \\
\hline $5,100-10,000$ & 1 & 14.3 & 12 & 38.7 & 2 & 14.30 & 12 & 50.00 & 3 & 27.30 \\
\hline $10,100-15,000$ & 2 & 28.6 & 2 & 6.5 & 6 & 42.9 & 0 & 0.0 & 2 & 18.2 \\
\hline $15,100-20,000$ & 1 & 14.3 & 0 & 0.0 & 0 & 0.0 & 0 & 0.0 & 0 & 0.0 \\
\hline$>21,000$ & 0 & & 0 & 0 & 0 & 0.0 & 0 & 0.0 & 0 & 0.0 \\
\hline \multicolumn{11}{|l|}{ Household size } \\
\hline $1-5$ & 3 & 42.9 & 8 & 25.8 & 10 & 71.4 & 13 & 54.2 & 4 & 36.4 \\
\hline $6-10$ & 4 & 57.14 & 19 & 61.3 & 2 & 14.3 & 8 & 33.3 & 5 & 45.5 \\
\hline$>11$ & 0 & 0 & 4 & 13.0 & 2 & 14.3 & 3 & 12.5 & 2 & 18.2 \\
\hline Total & 7 & 100 & 31 & 100 & 14 & 100 & 24 & 100 & 11 & 100 \\
\hline
\end{tabular}




\section{Macrothink}

\subsubsection{Demographic Characteristics of the Respondents that are Producers}

Table $3 \mathrm{~b}$ shows the result of the descriptive analysis of the administered questionnaire to the producers. Producers in the age range of 20-30years constituted $71.40 \%$ and $62.50 \%$ of the respondents in Gbanja and Greenhill respectively. In Palala and Zoweita greater percentage of the producers in the age range of 30-40years are $47.50 \%$ and $46.20 \%$ respectively. The producers share the same percentage of $33.30 \%$ across the age range of 20-30years and $30-40 y e a r s$ in Loita, majority of the producers in all the towns are male $(85.70 \%, 81.00 \%$, $75.00 \%, 69.20 \%$ and $83.30 \%$ ), Liberian engaged in charcoal production than any other nationalities, greater percentage of the respondents are literate with primary to tertiary qualification, the producers in the income range of LD\$5,000-30,000 represents the highest percentage of $42.90 \%, 47.60 \%, 62.50 \%, 38.50 \%$ and $66.70 \%$.Producers with the household size of 1-5 represented $52.40 \%$ in Palala, $46.20 \%$ in Zowetta and $50.00 \%$ in Loita. However, the household size of 6-10 constituted the highest percentage of $57.10 \%$ and $62.50 \%$ in Gbanja and Greenhill respectively. Majority of the respondents $(71.40 \%, 52.40 \%, 62.50 \%$, $61.50 \%$ and $100 \%$ ) have spent $1-5$ years on the business.

Table 3b. Demographic characteristics of the respondents that are producers

\begin{tabular}{|l|l|l|l|l|l|l|l|l|l|l|l|}
\hline Variable & \multicolumn{2}{l}{ Towns Gbarnja } & \multicolumn{2}{l|}{ Palala } & \multicolumn{2}{l|}{ Green hill quarry } & \multicolumn{2}{l|}{ Zoweita } & \multicolumn{2}{l|}{ Loita } \\
\hline Age & No & $\%$ & No & $\%$ & No & $\%$ & No & $\%$ & No & $\%$ \\
\hline $10-20$ & 0 & 0.00 & 1 & 4.700 & 0 & 0.00 & 0 & 0.00 & 0 & 0.0 \\
\hline $20-30$ & 5 & 71.40 & 5 & 23.80 & 5 & 62.50 & 4 & 30.70 & 2 & 3330 \\
\hline $30-40$ & 0 & 0.00 & 10 & 47.60 & 2 & 25.00 & 6 & 46.20 & 2 & 3330 \\
\hline 40 above & 2 & 28.60 & 5 & 23.80 & 1 & 12.50 & 3 & 23.10 & 2 & 3330 \\
\hline Gender & & & & & & & & & & \\
\hline Male & 6 & 85.70 & 17 & 81.00 & 6 & 75.00 & 9 & 69.20 & 5 & 8330 \\
\hline Female & 1 & 14.30 & 4 & 19.10 & 2 & 25.00 & 4 & 30.70 & 1 & 1670 \\
\hline Marital status & & & & & & & & & & \\
\hline Married & 2 & 28.60 & 12 & 57.10 & 3 & 37.50 & 6 & 46.20 & 4 & 6670 \\
\hline Single & 5 & 71.40 & 8 & 38.10 & 5 & 62.50 & 5 & 38.50 & 2 & 3330 \\
\hline Widow/widower & 0 & 0.00 & 1 & 4.7 & 0 & 0.00 & 2 & 15.40 & 0 & 0.00 \\
\hline Religion & & & & & & & & & & \\
\hline Islam & 1 & 14.30 & 2 & 9.50 & 0 & 0.00 & 2 & 15.40 & 0 & 0.0 \\
\hline Christianity & 6 & 85.70 & 19 & 90.5 & 8 & 100.0 & 11 & 84.60 & 6 & 10 \\
\hline Others & 0 & 0.00 & 0 & 0.00 & 0 & 0.00 & 0 & 0.00 & 0 & 0.0 \\
\hline Occupation & & & & & & & & & & \\
\hline Student & 2 & 28.60 & 3 & 14.30 & 5 & 62.50 & 3 & 23.10 & 0 & 0.0 \\
\hline Civil servant & 3 & 42.90 & 2 & 9.50 & 0 & 0.00 & 2 & 15.40 & 1 & 17 \\
\hline Private work e.g Traders & 2 & 28.6 & 16 & 76.2 & 3 & 37.5 & 8 & 61.5 & 5 & 83 \\
\hline Nationality & & & & & & & & & & \\
\hline Liberian & 6 & 85.70 & 17 & 81.00 & 6 & 75.00 & 12 & 92.30 & 6 & 10 \\
\hline Non-Liberian & 1 & 14.30 & 4 & 19.00 & 2 & 25.00 & 1 & 7.70 & 0 & 0.0 \\
\hline Level of Education & & & & & & & & & & \\
\hline
\end{tabular}




\begin{tabular}{|c|c|c|c|c|c|c|c|c|c|c|}
\hline Primary & 2 & 28.60 & 8 & 38.10 & 6 & 75.00 & 5 & 38.50 & 0 & 0.0 \\
\hline Secondary & 1 & 14.30 & 4 & 19.10 & 1 & 12.50 & 7 & 53.80 & 4 & 67 \\
\hline Tertiary & 3 & 42.90 & 7 & 33.30 & 1 & 12.50 & 0 & 0.00 & 0 & 0.0 \\
\hline Illiterate & 1 & 14.30 & 2 & 9.50 & 0 & 0.00 & 1 & 7.70 & 2 & 33 \\
\hline \multicolumn{11}{|c|}{ Monthly Income (LD\$) } \\
\hline$<5,000$ & 4 & 42.90 & 8 & 38.10 & 2 & 25.00 & 2 & 15.40 & 2 & 33 \\
\hline $5,100-10,000$ & 3 & 57.10 & 10 & 47.60 & 5 & 62.50 & 5 & 38.50 & 4 & 66 \\
\hline $10,100-15,000$ & 0 & 0.00 & 3 & 14.30 & 1 & 12.50 & 4 & 30.80 & 0 & 0.0 \\
\hline $15,100-20,000$ & 0 & 0.00 & 0 & 0.00 & 0 & 0.00 & 2 & 15.40 & 0 & 0.0 \\
\hline$>21,000$ & 0 & 0.00 & 0 & 0.00 & 0 & 0.00 & 0 & & 0 & 0.0 \\
\hline \multicolumn{11}{|l|}{ Household size } \\
\hline $1-5$ & 3 & 42.90 & 11 & 52.40 & 3 & 37.50 & 6 & 46.20 & 3 & 50 \\
\hline $6-10$ & 4 & 57.10 & 9 & 42.90 & 5 & 62.50 & 5 & 38.50 & 1 & 16 \\
\hline$>11$ & 0 & 0.00 & 1 & 4.80 & 0 & 0.00 & 2 & 15.40 & 2 & 33 \\
\hline \multicolumn{11}{|c|}{ Time spent on the business } \\
\hline $1-5$ & 5 & 71.40 & 11 & 52.40 & 5 & 62.50 & 8 & 61.50 & 6 & 10 \\
\hline $6-10$ & 2 & 28.60 & 5 & 23.80 & 2 & 25.00 & 4 & 30.70 & 0 & 0.0 \\
\hline $11-15$ & 0 & 0.00 & 1 & 4.80 & 1 & 12.50 & 1 & 7.70 & 0 & 0.0 \\
\hline $16-20$ & 0 & 0.00 & 1 & 4.80 & 0 & 0.00 & 0 & 0.00 & 0 & 0.0 \\
\hline $21-25$ & 0 & 0.00 & 3 & 14.30 & 0 & 0.00 & 0 & 0.00 & 0 & 0.0 \\
\hline Total & 7 & 100 & 21 & 100 & 8 & 100 & 13 & 100 & 6 & 10 \\
\hline
\end{tabular}

Source: Field Survey 2017

\subsection{Impacts of Charcoal Production on the Social life of the Inhabitants}

\subsubsection{Impacts of Charcoal Production on the Social Life of Consumers}

The result of the analysis of administered questionnaire revealed information on the negative social impact of the use of charcoal on the consumers. This include those that signified that the use of makes them fill sick (2.33\% of repondents in Palala; $14.29 \%$ in Green hill quarry; $16.67 \%$ in Zoweita). Also include those that indicated that the use of charcoal dirty their bodies/hands 42.86\%, 51.51\%, 42.86\%, 62.50\% and 45.45\% in Gbanga, Palala, Green hill quarry, Zoweitta and Loita respectively; dirty of their houses were also considered a negative social impact of the use of charcoal as well as smoke and ash dust were indicated by the respondents $(42.86 \%, 12.90 \%, 28.56 \%, 12.50$ and 9.09\% in Gbanga, Palala, Green hill quarry, Zoweitta and Loita respectively. Although, impact of smoke and ash is reported to be low as expressed by the respondents, however, nature of associated ailments and diseases with the burning cannot be medically substantiated due to lack of medical report. 
Table 4a. Impacts on the social life of Consumers

\begin{tabular}{|l|l|l|l|l|l|l|l|l|l|l|l|}
\hline Towns Variable & \multicolumn{2}{|l|}{ Gbarnga } & \multicolumn{2}{l|}{ Palala } & \multicolumn{2}{l|}{ Green hill quarry } & \multicolumn{2}{l|}{ Zoweita } & \multicolumn{2}{l|}{ Loita } \\
\hline & No & $\%$ & No & $\%$ & No & $\%$ & No & $\%$ & No & $\%$ \\
\hline Sickness/illness & 0 & 0.00 & 1 & 2.23 & 2 & 14.29 & 4 & 16.67 & 0 & 0.00 \\
\hline Dirty the body & 3 & 42.86 & 17 & 51.51 & 6 & 42.86 & 15 & 62.50 & 5 & 45.45 \\
\hline Dirty the house & 1 & 14.28 & 9 & 29.03 & 2 & 14.29 & 2 & 8.33 & 5 & 45.45 \\
\hline Smoke and ash & 3 & 42.86 & 4 & 12.90 & 4 & 28.56 & 3 & 12.50 & 1 & 9.09 \\
\hline Total & $\mathbf{7}$ & 100.00 & 31 & 100.00 & 14 & 100.00 & 24 & 100.00 & 11 & 100.00 \\
\hline
\end{tabular}

Source: Field Survey 2017

\subsubsection{Impacts of Charcoal Production on the Social Life of the Producers}

Analysis of the result obtained from the data generated on the response of the producers on the impacts of the charcoal production on their social life revealed that greater percentage of the producers in Gbanja (57.14\%) indicated that the production dirty their bodies unlike respondents in Palala (66.67\%). The impact of charcoal production was indicated to be high in Gbanga than all other towns. Dirty the body of the producers was the greatest social impact (66.70\%) that was observed in Loita. The gases emitting with the smoke and ash from the incomplete combustion of the wood as observed during the production are clear indications that the producers are susceptible to respiratory ailments and diseases. The air is polluted with thick, dark smoke suspected to contain soot or particle matter, carbon dioxide, and carbon monoxide. Other chemicals, ailments and diseases associated with the emitted smoke and ash cannot be authenticated due to absence of laboratory analysis. However, the producers complain of experiencing respiratory difficulties in the night after the exercise.

Table 4b. Impact of charcoal production on the Social life of the producers

\begin{tabular}{|l|l|l|l|l|l|l|l|l|l|l|l|}
\hline Towns Variable & \multicolumn{2}{l|}{ Gbarnja } & \multicolumn{2}{l|}{ Palala } & \multicolumn{2}{l|}{ Green hill quarry } & \multicolumn{2}{l|}{ Zoweita } & \multicolumn{2}{l|}{ Loita } \\
\hline & No & $\%$ & No & $\%$ & No & $\%$ & No & $\%$ & No & $\%$ \\
\hline Sickness/illness & 1 & 14.29 & 3 & 16.67 & 1 & 0.00 & 3 & 57.10 & 2 & 33.30 \\
\hline Dirty the body & 4 & 57.14 & 12 & 66.67 & 5 & 100.00 & 2 & 42.90 & 3 & 66.70 \\
\hline Smoke and ash & 2 & 28.57 & 3 & 16.66 & 2 & 16.66 & 2 & 0.00 & 1 & 0.00 \\
\hline Total & 7 & 100.00 & 18 & 100.0 & 8 & 100.00 & 7 & 100.00 & 6 & 100.00 \\
\hline
\end{tabular}

Source: Field Survey 2017

\subsection{Economic Impact of Charcoal Production on the Inhabitants}

Price of charcoal

Analysis of the market survey conducted revealed that the selling price of charcoal varies from one community to the other. It also revealed that as one is moving away from the bigger towns and villages the price tend to decrease. The average price of selling a bag of charcoal 
in Gbanja, Palala and Green Hill quary was the same at the rate of LD175, whereas it was at the rate of LD 150 in Zoweita and Loita. A polythene bag of charcoal is being sold at LD20. Average weight of a coal bag is about $20-25 \mathrm{~kg}$

Quantity consume

Quantity consume was measured based on whether the consumer buys in bag or at a small size in a plastic bag.

Table 5. Quantity consume

\begin{tabular}{|c|l|l|l|l|l|}
\hline Quantity & Gbanga & Palala & Green Hill quarry & Zoweita & Loita \\
\hline Plastic bag per day @ the rate of LD20 & 2 & 18 & 4 & 16 & 3 \\
\hline A bag per week @ the rate of LD175 & 5 & 13 & 9 & 8 & 8 \\
\hline
\end{tabular}

Source: Field Survey 2017

Amount spend on the purchase of charcoal per month (at 30 days in a month and 4 weeks in a month)

Gbanga: 2 x $30 \times$ LD20 = LD 1200 - This is the calculated amount for those that purchase in polythene bag $5 \times 4 \times$ LD $175=\mathrm{LD} 3500$ - This is calculated amount for those that purchase in bag. Total amount spend on charcoal per month $=$ LD1200 + LD 3500 $=$ LD4700

Average amount spent on charcoal production per month LD4700/7 = LD 671.43

Palala: $18 \times 30 \times$ LD $20=$ LD10,800 - This is the calculated amount for those that purchase in polythene bag $13 \times 4 \times$ LD $175=$ LD 9100 - This is calculated amount for those that purchase in bag. Total amount spend on charcoal per month $=$ LD19,900. Average amount spent on charcoal production per month LD19,900/31 = LD 641.94

Green hill quarry: 4 x $30 \times$ LD $20=$ LD2400. This is the calculated amount for those that purchase in polythene bag, $9 \times 4 \times$ LD $175=$ LD6300. This is calculated amount for those that purchase in bag. Total amount spend on charcoal per month $=$ LD8700

Average amount spent on charcoal production per month LD8700/ $31=$ LD 669.23

Zoweita: 16 x 30 x LD $20=$ LD 9600. This is the calculated amount for those that purchase in polythene bag $8 \times 4 \times 175=\mathrm{LD} 5600$. This is calculated amount for those that purchase in bag

Total amount spend on charcoal per month = LD15, 200

Average amount spent on charcoal production per month $=$ LD15,200/24 = LD 633.3

Loita : 3 x $30 \times$ LD20 = LD1800. This is the calculated amount for those that purchase in polythene bag

$8 \times 4 \times$ LD $175=$ LD 5600. This is calculated amount for those that purchase in bag

Total amount spend on charcoal per month $=$ LD7, 400 
Average amount spent on charcoal production per month LD7400/11 = LD 672.72

Table 6. Cost of living in the communities

\begin{tabular}{|l|l|l|l|l|l|l|l|l|l|l|}
\hline Town Variable & \multicolumn{2}{l|}{ Gbanja } & \multicolumn{2}{l|}{ Palala } & \multicolumn{2}{l|}{ Green Hill quarry } & \multicolumn{2}{l|}{ Zoweitta } & \multicolumn{2}{l|}{ Loiita } \\
\hline $\begin{array}{l}\text { Cost of living (LD\$) (money } \\
\text { spent on food, and purchase of } \\
\text { household items per month) }\end{array}$ & No & $\%$ & No & $\%$ & No & $\%$ & No & $\%$ & No & $\%$ \\
\hline$<3,900$ & 1 & 14.29 & 0 & 0.00 & 0 & 0.00 & 5 & 20.83 & 0 & 0.00 \\
\hline $4000-6000$ & 6 & 85.70 & 21 & 67.74 & 9 & 64.28 & 19 & 79.17 & 10 & 90.90 \\
\hline $6100-8000$ & 0 & 0.00 & 6 & 19.36 & 4 & 28.57 & 0 & 0.00 & 1 & 9.09 \\
\hline $8100-10,000$ & 0 & 0.00 & 4 & 12.90 & 1 & 7.14 & 0 & 0.00 & 0 & 0.00 \\
\hline Total & 7 & 100 & 31 & 100 & 14 & 100 & 24 & 100 & 11 & 100 \\
\hline
\end{tabular}

Source: Field Survey 2017

Table 7. Achievement as gains from the production of Charcoal

\begin{tabular}{|l|l|l|l|l|l|l|l|l|l|l|l|}
\hline \multicolumn{2}{|r|}{ Town } & \multicolumn{2}{l|}{ Gbanja } & \multicolumn{2}{l|}{ Palala } & \multicolumn{2}{l|}{$\begin{array}{l}\text { Green Hill } \\
\text { quarry }\end{array}$} \\
\hline ACriable & No & $\%$ & No & $\%$ & No & $\%$ & No & $\%$ & No & $\%$ \\
\hline Education(Children) & 5 & 71.42 & 15 & 71.42 & 8 & 100.00 & 6 & 46.15 & 3 & 50.00 \\
\hline Building (Accomodation) & 2 & 28.57 & 4 & 19.05 & 0 & 0.00 & 3 & 23.08 & 1 & 16.67 \\
\hline $\begin{array}{l}\text { Betterliving (feeding, clothing, } \\
\text { improve environment) }\end{array}$ & 0 & 0.00 & 2 & 9.52 & 0 & 0.00 & 4 & 31.08 & 2 & 33.33 \\
\hline Total & 7 & 100.00 & 21 & 100.00 & 8 & 100.00 & 13 & 100.00 & 6 & 100.00 \\
\hline
\end{tabular}

Source: Field Survey 2017

To measure the gains from the production of charcoal is very difficult. The researchers therefore result to the use of yardstick for measuring their achievement. The yardstick includes providing education fee to sponsor their wards, building personal houses and improvement in their standard of living.

\section{Discussion}

\subsection{Demographic Characteristics of the Respondents}

The result obtained from the analysis of demographic characteristic of the respondents revealed that greater percentages of the consumers $(71.40 \%, 51.60 \%, 42.90 \%$ and $36.40 \%$ ) are between the age ranges of 21-30years. Similar result was obtained for the producers except in Palala and Zoweita where the highest percentage of the inhabitants that are producer were in the age range of 30 to 40 years representing $47.60 \%$ to $46.20 \%$. This support the report of 2010 revision of the World Population Prospects in Liberia. According to this report, the proportion of children in Liberia below the age of 15 in 2010 was $43.5 \%$, $53.7 \%$ was between 15 and 65 years of age, while $2.8 \%$ was 65 years or older. 
This is a clear indication that inhabitants of these communities are in their economic and active age range of between 20 to 40years. Tunde et.al, 2013 opined that people in this age range offers opportunities for labour that is needed in the production of charcoal since the traditional method is highly labour intensive. The authors emphasized availability of labour as another opportunity provided in any community that are presence of people in the age category of between 20-40 years. The need to consider gender difference among the consumers and the producers of charcoal in this study was drawn from the the report on Gender and Energy Desk Review of African Development Bank Group (ADBG)(2016) focus on gender approaches to the renewable energy sector in Africa.

It was reported in this study that energy poverty on the Africa continent is gendered; there are different gender-defined roles in energy production, distribution and use in households, communities and the market. Therefore, women and men experience energy poverty differently. Analysis of the result obtained on the demographic characteristic of the respondents indicated that large percentage of the consumers are women $(71.40 \%, 61.20 \%$, $82.70 \%$ and $63.60 \%)$ while the majority of the producers are male $(85.70 \%, 81.00 \%, 75.00 \%$, $69.20 \%$ and $83.30 \%$ ). Brouwer and Falcao, 2004, emphasized that majority of charcoal is consumed by household for cooking and heating whilst a small percentage is consumed by commerce and industry. Köhlin (2011) found that "women spend 3-5 times as much time as men on domestic activities. This explains the reason why women represent greater percentage of the consumers in the study communities. Lack of access to natural resources for instance trees that are used in the production of charcoal might deny women opportunity to participate in charcoal producers as observed in these communities. Global Gender and Climate Alliance, 2011 opined that women are generally disadvantaged in terms of ownership and access to land, natural resources, credit, information and decision-making, at all levels.

Charcoal production is a source of employment for the citizen of Liberia since many of the producers are Liberians (75-92\%) while relatively few percentages of the producers are non-citizen $(7.7-25 \%)$.

\subsection{Economic impacts of Charcoal production}

Income range of the consumers in the selected communities was observed to be varied. Greater percentage of the consumers are in the low income range of <LD5000 per month expending between LD 633.30 to LD672.72 representing $13 \%$ to $25 \%$ of their income on charcoal consumption. The figure obtained is close to the one reported by ADBG, 2016that households in Africa typically spend $20-25 \%$ of their income on kerosene even though the cost of using it for lighting (measured as \$/lumen hour of light) can be 150 -times higher than that provided by incandescent bulbs and 600-times higher than that from compact fluorescent lights. Many reasons can be adjudged from the amount being expended on purchase of charcoal as observed in this part of Liberia. One of the reasons is high dependent of Liberia on importation of fossil fuel for domestic and commercial use. This invariable makes the landing cost of this essential commodity to be very high as reflected on the selling price that is beyond the reach of common man.

Ellegard and Nordstrom, 2003 observed that the demand for charcoal is due to its low cost 
compared to other fuels like kerosene and liquefied petroleum gas Mugo and Ong (2006), recalled that while electricity and gas may be considered the most desired cooking fuels, most households cannot afford both the energy resource and the devices required to use these forms of energy. The author considered this as the reason why many people, therefore, turn to using kerosene or charcoal. Another reason for consuming charcoal in the studied communities is due to lack of access to electricity.

One percent of the Liberia population is connected to electricity grid of which $95 \%$ rely on traditional biomass fuels in the form of wood and charcoal (Goanue, 2009). According to UN-Energy, 2005one of the critical issues preventing poverty reduction in developing countries is the provision of energy. Currently 1.6 billion people lack access to electricity, whilst 2.4 billion are deprived of modern fuels for cooking and heating (UN-Energy, 2005). Lack of energy constrains the delivery of social services, limits opportunities for women and erodes environmental sustainability. With these reasons that have been identified it has been predicted that the rate of consuming charcoal will double by 2030 with over with over 700 million Africans relying on it as a durable, preferred, and cheap source of energy (Ishengoma and Kappel, 2006).

Cost of living in these communities was identified to be in the range of LD4000-6000 as indicated by the respondents in Gbanja (85.70\%), Palala (67.74\%), Green hill quarry $(64.28 \%)$, Zoweitta $(79.17 \%)$ and Loitta $(90.90 \%)$. If the income range of majority is less than LD5000 it clearly shows that by the time the cost of charcoal (633.30 to LD672.72) is deducted from their income and with high cost of living (LD4000-6000) many of them will be left with little or nothing for the month. The implication of this is that many of term are living below the poverty line with little or no saving at the end of the month. This is also another factor that constitutes to the use of Charcoal as a form of energy for cooking and heating in this part of Liberia. UN-Energy, 2005, reported that energy provision is a basic human need and consumption is closely related to the level of a country's development as reflected in the income of the citizens. This is observed in the poor Human Development Index (HDI) 1 scores and the low energy consumption of Sub-Saharan Africa (SSA) as well as many other developing countries as reasons for their heavily dependent upon wood fuels for their energy requirements (Arnold et al., 2003).

On the other hand charcoal production has contributed to the economic wellbeing of the producers through increase income earning. The analysis of the data obtained from the producers revealed that the producers are high income earners with the income range of between LD5,000 and20,000 per month. The production of charcoal therefore served as means of generating income and generating employment. Ccharcoal industries in some of the top producing countries, namely Tanzania and Uganda, employ tens to hundreds of thousands of citizens, many of whom receive up to $70 \%$ of their annual income from this market (Arnold et.al, 2006, Goanue, 2009; Zulu and Richaddson, 2013).Arriving at the actual profit from the sales of charcoal was a bit difficult since this depends on the result obtained on other cost of production such as the cost of purchasing empty bag, cost of renting the power saw machine, cost of hiring labour /employment, cost of living, cost of the tree felled as wood e.t.c. Since the cost of these variable are not fixed and depend mostly on the bargaining power and 
negotiation it was difficult to arrive at the unit cost per bag of charcoal.

The best that could be done in this situation as measure of their economic benefits was to ask questions that could be associated with their gains over a certain period of five years. The researcher therefore resolved to make use of certain parameters such as mentioning their achievements since their involvement in charcoal production in the last five years. Some of the achievements mentioned include charcoal production served as source of financing their children education, source of money for building personal houses and improve living condition. Source of financing their children education recorded the highest percentage of $71.42 \%$ for the producers in Gbanja and Palala, all the respondents in Green hill quarry agreed to this term together with $46.15 \%$ and $50.00 \%$ of producers in Zoweitta and Loitta respectively. Charcoal production as a form of fuel wood has therefore contributed to the livelihood of the people in term of source of income to meet their needs. This supports research findings as reported in literatures that charcoal production is one of the main livelihood components of the rural poor in Sub Sahara Africa (SEI, 2002; Kituyi, 2004; Girard, 2002).

For many more, the activity acts as a supplemental source of income, "a safety net" in times of hardship (Arnold et al., 2006). Mutimba (2005) demonstrated this in Kenya where there were over 200,000 charcoal producers, and over half a million people (producers, transporters and vendors) were directly involved in the trade. Arnold, (2001) reported that the dependence on fuelwood is based on a subsistence strategy to supplement inputs, such as fuel, food and medicinal plants, or to help diversify the source of income in times of hardship. The researcher emphasised that it is the poorer households that depend on forests for a larger share of their overall livelihood. For others, predominantly the 240 million forest dwellers worldwide, forest resources meet almost all of their daily needs (Sunderlin et al., 2005). It can therefore deduce from this study that production of charcoal constitutes major source of income for the producers in these communities as a source of employment and income to meet their family need since many of the producers are earning (LD5100-10,000) which is above average cost of living (LD4000- 6000) in these communities. This support the findings of FAO,2001 that majority of Africa's population (63\%) live in rural areas, where subsistence agriculture is the principal livelihood strategy in addition to collection of firewood and charcoal production .

\subsection{Social impact of Charcoal production on the inhabitants}

Social impacts of charcoal production on the consumers in the selected communities were observed to be in four ways including inflicting sickness/illness, dirty the hands of the users, dirty their houses and the building and other environmental menace such as generating smoke and ash/dust. The environmental impacts of charcoal production as stated by the consumers have a lot of implication on their health. The health issues concerning the use of charcoal especially where there are incomplete combustion resulting to pollution of the living conditions has been reported to significantly reducing the welfare of women and directly responsible for the death of more than 1.6 million people annually worldwide (400,000 SSA) due to respiratory diseases (Khandelwal et al., 2017). ADBG, 2016 emphasized some of the 
challenges faced by the majority of African women and girls to include adverse health effects due to exposure to respiratory diseases (as a result of indoor air pollution from cooking with traditional biomass) and ill safety issues encountered while gathering fuel wood.

Since large percentage of the consumers in these communities are women in the age range of 20-40 years it clearly support the findings of ADBG, 2016 that rural women and girls are especially affected as the majority of energy is derived from traditional biomass fuels such as wood, charcoal and agricultural waste.Although the nature of impact was observed to be different from one community to the other, however inflicting sicknesses, dirty the hands and houses and generating smoke were observed in all the communities. Dirty of the bodies and houses recorded the highest percentage in all the communities in the following order $42.86 \%$, $51.51 \%, 42.86 \%, 62.50 \%$ and $45.45 \%$ in Gbanga, Palala, Green hill quarry, Zoweitta and Loita respectively. This was followed by the percentage of respondents on environmental impacts of charcoal consumption $(42.86 \%, 12.90 \%, 28.56 \%, 12.50$ and $9.09 \%$ in Gbanga, Palala, Green hill quarry, Zoweitta and Loita respectively).

The social impacts of charcoal production on the social life of the producers as obtained in this study is quite revealing. Large percentage of the producers in Loita $(66.70 \%)$ indicated that the production of charcoal dirty their bodies compared to their counterpart in Palala (66.67\%) and Gbanga (57.14\%). Smoke and ash was indicated to have high impact on the consumers that are inhabitants of Gbanga. Although there was no cases of death or ailments associated with smoke and ash by both the consumers and the producers, however this can not be ignored considered the nature of the smoke and associated gases being emitted. Young, 2012 opinmed that smoke inhalation is severly dangerosus because many people may not show symptons until 24 to 48 hours after the event. The author emphasized that $50-80 \%$ of death are from smoke inhalation and not from body burnt mainly because smoke contain chemicals such as benzene, toluene, styrene, aldehydes, acid gases, nitrogen oxides, sulfur dioxide, and metal and dioxins that are very injurious to human health. Exposure to smoke typically causes eye, nose and throat irritation, shortness of breath or chest pains (New York City, Environment and Health portal, 2012)

The number one cause of death when it comes to fires is smoke inhalation. Smoke inhalation damages the body by asphyxiation (lack of oxygen), chemical irritation, or a combination of the two. Smoke itself can be harmless to you but it takes up the space needed for oxygen, similar to carbon dioxide. Smoke inhalation is especially dangerous because people may not show symptoms until 24 to 48 hours after the event. An estimated 50-80\% of fire deaths are from inhalation, not burns.

According to Tunde et al., 2013, at each stage of charcoal there are impacts on both the environment and human health. This also support findings of Oguntade et al., 2008; and Wahbu et al., 2015, the authors emphasized the impact of charcoal production on human health, soil minerals and depletion of the ozone layer.

The environmental impact of charcoal production has been attributed to occurrence of unpredictable climate change with resultant cumulative threat on food production and the increase in epidemics. As demand for charcoal increases with rapid urbanization, so does 
pressure on forests and woodlands, most of which are poorly managed and prone to degradation. The rate of exploitation and ridiculous amount charge on the tree are serious indication that this forest resource is being exploited indiscriminately with little or no return to the owners or government. Forest depletion and air pollution are form part of environmental impacts of charcoal production as identified in some literatures. European Commision-DG Environment, 2002 emphasizes that for many years, environmental policy has focused on resolving the most urgent problems as regards environmental pollution, to a large extent by focusing on end-of-pipe technologies. More and more, the public and policy makers are also directing attention to the need for reducing resource use and its impact on the environment. This is inter alia reflected in the 6th EU Environmental Action Programme, which identifies improved "Resource efficiency and management" as one of its key objectives.

There is therefore a need to improve on the method of production through provision of modern technology for charcoal production. This will go a long way in reducing identified environmental challenges such as pollution, dirty of hands and houses and other health related problem. The release of gaseous substances such as carbon dioxide, Nitrogen oxide, Sulphur dioxide and Methane into the atmosphere during charcoal production is always in form of smoke which is considered to be injurious to human health (Smith, 2002)). In October 1996, the European Commission published a Directive on Integrated Pollution Prevention and Control (IPPC). The IPPC Directive is designed to prevent, reduce and eliminate pollution (of all natures) at source through the efficient use of natural resources. It is intended to help operators of such premises to move towards greater environmental sustainability.

However, relatively few countries have conformed to this directive with exception of England and Wales through the Pollution Prevention and Control (PPC) Regulations 2000. If developing countries like Liberia comply with IPPC directive it will go a long way in addressing issues related to emission of pollutant during the course of producing charcoal energy. Rather than using traditional earth kiln method of charcoal production as observed throughout the selected communities, modernized techniques of charcoal production such as metal jumbo kiln, Beehive kiln (Brazilian type), Conical earth mound kiln, earth mound kiln, Masonry kilos (Half orange Argentinean and Brazilian design) and Paralytic drum technique should be adopted in order to promote efficient use wood for charcoal production (Netherlands Programme on Sustainable Biomass, 2013, Ukranian Biofuel Suppliers, 2016).

\section{Conclusion}

Production of charcoal through various traditional earth kiln methods served as source of income to the inhabitants of Kpai district, Bong County Liberia. Majority of people engaging in the act of production are male in their active age range and they are citizen of Liberia. The increasing demand for the product to meet domestic needs such as cooking, heating e.t.c is largely due to some factors. Affordability, lack of access to alternative energy like kerosine, poverty as a result of poor economic down turn in the war torn country and women constituted highest percentage of the consumers are adjudged to be responsible for increasing 


\section{I Macrothink}

demand for charcoal in the study areas. The social and health issues associated with the consumption of charcoal are of serious concern that cannot be ignored mainly because majority of the consumers are women and girls at their young ages. Some of the negative social impacts identified include inflicting sickness/illness on the consumers, dirty of hands, the walls and floors of their buildings with air pollution from smoke and ash/dust. Forest areas are not spared from this environmental menace since they constitute source of wood which is the major raw materials for this product. Trees and shrubs are felled indiscriminately in the quest to satisfy their raw materials demand thereby degrading capacity of the forest to serve as carbon sinkers. The effect of deforestation manifested in an unpredictable climate phenomenon with attendant cumulative threat on food production and increase in epidemics. Increasing rate of exploitation with absence of plough back strategy from the proceeds realise through the ridiculous amount charge on the trees fell are serious indication that the forest resource is being exploited unsustainably. The positive economic impacts of charcoal production in these communities can be exploited through improvement in the method of production. Modernised techniques of charcoal production will go a long way in addressing the issue of air pollution and other associated social and environmental menace as was outstretched in this study. Liberia will enlist herself in the committee of nations that are producing charcoal in compliance with the directive of IPPC if modern techniques of charcoal production are imbibed.

\section{References}

African Development Bank Group (ADBG) (2016): Empowering Women in Africa through access to Sustainable Energy: A desk review of gender-focused approaches in the renewable energy sector.

African Review of Business and Technology (ARBT) (2006). "Bio-fuels", Bureau of Public Enterprises (BPE), "Nigerian Power Sector Reform Document", BPE

Arnold, M. J. E. (2001). Forestry, Poverty and Aid. CIFOR Occasional Paper No. 33. http://www.cifor.cgiar.org.

Arnold, M., Kohlin, G., Persson, R., Shepherd, (2003). Fuelwood revisited. What has changed in the last decade? Centre for International Forestry Research Occasional Paper, No. 39.

Arnold, M. J. E., Kohlin, G., \& Persson, R. (2006). Woodfuels, Livelihoods, and Policy Interventions: Changing Perspectives. World Development, 34(3), 596-611.

https://doi.org/10.1016/j.worlddev.2005.08.008

Audu E. B. (2013): Fuel Wood Consumption and desertification in Nigeria. International Journal of Science and Technology, 3, 1-5.

Brouwer, R., \& Falcao, M. P. (2004). Wood Fuel Consumption in Maputo, Mozambique. Biomass and Energy, 27, 233-245. https://doi.org/10.1016/j.biombioe.2004.01.005

Cunha, J. P. (2012). Do, FACOEP Activated Charcoal. 


\section{Macrothink}

Environmental Management and Sustainable Development

ISSN 2164-7682 2018, Vol. 7, No. 2

Ellegard, A., \& Nordstrom, M. (2003). Deforestation for the poor? Renewable Energy

Energy Information Administration, (2001). International Energy Outlook. Washington, D.C.

FAO, (1985) Industrial Charcoal Making, FAO Forestry paper No. 63, Rome

FAO (1987): Simple technologies for charcoal making

FAO, (1998) Wood fuel review and assessment in Liberia

FAO, (1993) A decade of wood energy activities within the Nairobi programme of Action. FAO Forestry paper No. 108, Rome.

FAO (2001). Agricultural and rural extension worldwide. Options for institutional reform in the developing countries. FAO, Rome.

Girard, P. (2002). Charcoal production and use in Africa: What Future? Unasylva, 211(53), 30-34

Global Gender and Climate Alliance, (2011). Gender and Climate Change Capacity Development Series - Africa Module 3 - Energy. Working Draft. Available at: www.uncclearn.org/sites/default/files/inventory/undp120.pdf

Goanue, A. V. (2009). Status of Renewable Energy in Liberia. Presentation of Rural and Renewable Energy Agency.

Ishengoma, E., \& Kappel, R. (2006). Economic growth and poverty: does formalization of informal enterprises matter? German Institute of Global and Area studies. Working Paper, GIGA Hamburg.

Jamala, G. Y, Abraham, P, Joel, L., \& Asongo, A. (2013). Socio-Economic Implications of Charcoal Production and Marketing in Nigeria. Journal of Agriculture and Veterinary Science (IOSR-JAVS), 5(4), 41-45. https://doi.org/10.9790/2380-0544145

Karekezi, S. (2002). Poverty and energy in Africa - A brief review. Energy Policy. 30, 915919. https://doi.org/10.1016/S0301-4215(02)00047-2

Khandelwal, M, Hill Jr., M. E, Greenough, P., \& Anthony, J. (2017): Why Have Improved Cook-Stove Initiatives in India Failed?. World Development, 92, 13-27.

https://doi.org/10.1016/j.worlddev.2016.11.006

Kituyi, E. (2004). Towards Sustainable Production and Use of Charcoal in Kenya: Exploring the Potential in Life Cycle Management Approach. Journal of Cleaner Production, 12, 1047-1057. https://doi.org/10.1016/j.jclepro.2004.02.011

Liberian Forestry Development Authority (2006). National Forestry Policy and Implementation Strategy. Republic of Liberia.

Madubansi, M., \& Shackleton, C. M. (2007). Changes in fuelwood use and selection following electrification in the Bushbuckridge lowveld, South Africa. Journal of Environmental Management, 83(4), 416-26. https://doi.org/10.1016/j.jenvman.2006.03.014 
Ministry of Land, Mines and Energy (MLME). (2009). National Energy Policy. Republic of Liberia

Mungo, F., \& Ong, C. (2006): Lessons from eastern Africa's Unsustainable Charcoal Trade, ICRAF World Agroforestry Centre.

Msuya, N., Enock, M., \& Abrahamu, K. T. (2011). Environmental Burden of Charcoal Production and Use in Dar es Salaam, Tanzania. Journal of Environmental Protection, 2, 1364-1369. https://doi.org/10.4236/jep.2011.210158

Mutimba, S. (2005). National Charcoal Survey of Kenya: Exploring Potential for Sustainable Charcoal Industry in East Africa.

http://www.partners4africa.org/docs/S2-7-Mutimba-PfA-Tanzania-0506.pdf.

New York City, Environment and Health portal, 2012 [online] Available: https://www1.nyc.gov/site/doh/health/health-topics/air-quality-fire-smoke-and-effect-on-air-q uality.page (Oct. 2017)

Netherlands Programme on Sustainable Biomass, 2013.

Nwofe P. A. (2013): Comparative analysis of domestic energy use in Nigeria: Renewable energy. Continental Journal, 4(1), 7-17.

Obayelu, A. E., Lawal, I. B., \& Omotuyole, I. A. (2017). Comparative Analysis of Access, and Preferences of Rural and Urban Households for Cooking Energy, and the Determinants in Nigeria: A Case of Ogun State, Agricultura Tropica Et Subtropica, 50(1), 45-53

Ogara, Isaac J, (2011) .Preliminary studies on charcoal production and producers' knowledge of environmental hazards in Nasarawa state, Nigeria. PAT (2): 68-75 ISSN: 0794-5213.

Oguntade, P. G., Abiodun, B. J., Ajayi, A. E., \& van de Giesen, N. (2008). Effect of Charcoal Production On Soil Physical Properties In Ghana. Journal of Plant Nutrition and Soil Science 171, 591-596. https://doi.org/10.1002/jpln.200625185

Oladeji, S. O. (1998). Effect of increase in the price of kerosene on fuelwood consumption in Akure South Local Government Area of Ondo-State, Nigeria. Unpublished thesis submitted to the Department of Forestry and Wood Technology, Akure, Nigeria , pp200

Okello, C., Pindozzi, S., Faugno, S., \& Boccia, L. (2013). Development of bioenergy technologies in Uganda: A review of progress. Renewable and Sustainable Energy Reviews. 18, 55-63. https://doi.org/10.1016/j.rser.2012.10.004

Prasad, G. (2008). Energy sector reform, energy transitions and the poor in Africa. Energy Policy. 36(8), 2806-2811. https://doi.org/10.1016/j.enpol.2008.02.042

SEI, (2002). Charcoal Potential in Southern Africa, CHAPOSA. Final Report. INCODEV. Stockholm, Stockholm Environment Institute.

Smith, K. R (2002). Indoor air pollution in developing countries: recommendations for research. International Journal of Indoor Environment and Health, 12(3), 198-207. 
https://doi.org/10.1034/j.1600-0668.2002.01137.x

Stefan, H. (2009). Renewable energy in Ethiopia: 13 Months of sunshine for a sustainable development Germany (pp. 1-20). Retrieved from

http://www.stefanheimann.eu/inhalt/Renewables_Ethiopia.pdf.

Sunderlin, W. D., Angelsen, A., Belcher, B., Burgers, P., Nasi, R., Santoso, L., \& Wunder, S. (2005). Livelihoods, Forests and Conservation in Developing Countries: An Overview. World Development, 33(9), 1383-1402. https://doi.org/10.1016/j.worlddev.2004.10.004

Tunde, A. M., Adeleke, E. A., \& Adeniyi, E. E. (2013). Impact of Charcoal Production on the Sustainable Development of Asa Local Government Area, Kwara State, Nigeria. African Research Review An International Multidisciplinary Journal, Ethiopia, 7(2), 1-15.

https://doi.org/10.4314/afrrev.v7i2.1

The Schumacher Centre for Technology and Development (2005): Charcoal production: Practical action. Technology challenging poverty [online] Available:

http://practicalaction.org/practicalanswers/ (December, 2017)

Ukranian Biofuel Suppliers, 2016

UN-Energy. (2005). The Energy Challenge for Achieving the Millennium Development Goals. http://esa.un.org/un-energy/pdf/UN-ENRG\%20paper.pdf.

UNDP (2004). World Energy Assessment, United Nations Development Program, New York, ISBN: 92-1-126167-8, www.undp.org/energy.

World Health Organisation (WHO). (2006). Fuel for Life: Household Energy and Health, Geneva: WHO.

Wahbu. S, Fosu-Mensah B. Y., \& Nyame F. K. (2015). Impact of Charcoal Production on Physical and Chemical Properties of Soil in the Central Gonja District of the Northern Region, Ghana. Environment and Natural Resources Research, 5(3), 2015.

Young, K (2012). Smoke and ash inhalation related to wildfires. Geology and human health. Tropical resources [online] Available:

https://serc.carleton.edu/NAGTWorkshops/health/case_studies/smoke_ash.html (October, 2017)

Zulu, Leo, C., \& Richardson, R. B. (2013). Charcoal, livelihoods and poverty reduction: Evidence from sub-Saharan Africa. Energy for Sustainable Development, 17, 127-137. https://doi.org/10.1016/j.esd.2012.07.007

\section{Copyright Disclaimer}

Copyright for this article is retained by the author(s), with first publication rights granted to the journal.

This is an open-access article distributed under the terms and conditions of the Creative Commons Attribution license (http://creativecommons.org/licenses/by/3.0/). 